[Town, S. (1995). Are You Gay, Sir? A Review of the Literature Concerning the Experiences of Gay Male Educators. New Zealand Annual Review of Education, 4, 207-227]

\section{Are You Gay, Sir? A Review of the Literature Concerning the Experiences of Gay Male Educators}

\author{
SHANE TOWN
}

\section{Abstract:}

This article reviews the literature available from overseas and in Aotearoa that investigates the experiences of gay and lesbian teachers in secondary schools. In doing so it explores the role that homophobia and heterosexism play in creating school environments that are often hostile to lesbian and gay teachers and students. These "forces" operate to maintain the segregation between gay and lesbian youth and gay and lesbian teachers creating a climate of fear based on myths of paedophilia, recruitment and deviancy. The damaging effects of this institutionalised homophobia on the daily lives of gay male teachers is examined. Using overseas experience as a guide suggestions as to how to create safe schools for lesbian and gay students and teachers are explored.

$\mathrm{H}$ istorically, the issue of homosexuality and its place in the education arena has been characterised by the silence surrounding t. Research has tended to concern itself with the causes of homosexuality, rather than with the problems encountered by lesbians and gay males living and working within a heterosexist society. As a result of this focus little has been done to explore how the lesbian or gay male educator copes within the predominantly homophobic education institutions she/he has to work within. The purpose of this review is to examine the issues that were confronting gay male teachers within education institutions in 1994.

Up until 1993 and the passing of the Human Rights Amendment Act to be an "out" gay teacher in Aotearoa was a professional risk. The legislation that is now in place in theory protects the gay teacher from discrimination on the grounds of his sexual orientation. It provides for a climate in which the issues surrounding gay and lesbian concerns in education and elsewhere can be raised and a discourse focusing on change can be initiated. A necessary part of this discourse will be an exploration of the forces of homophobia and heterosexism and how they are manifested in the school and community contexts. If discrimination against the gay or lesbian teacher and the gay or lesbian student is to cease, politicians, policy makers and school administrators will need to listen carefully to the concerns of the lesbian and gay community and learn from overseas experience.

The research on this topic which is now available, although not readily accessible in Aotearoa has begun to present the experiences and views of lesbian and gay students and educators. This review will explore the literature that is available concerning gay male educators, examine the common themes and principles underlying the research and reflect on their findings. To do this an examination of the nature of the silence that renders the needs and existence of gay male educators invisible will be necessary along with an examination of the effects that this has on their lives. The findings of the research will be presented thematically followed by the contribution the literature will make to study I have undertaken. This will involve a critical evaluation of the material, identifying the gaps and silences that need to be addressed in a New Zealand context.

\section{Silence and Invisibility}

Homophobia, the fear of homosexuals, and heterosexism, the replication of heterosexual ideals in educational institutions are the forces that help to reinforce gender stereotyping and rigid sex roles. The fear of being labelled lesbian or gay keeps many students and educators "in their place" and prevents them from participating in the full life of the institutions in which they study and work. The reasons for prejudice are varied, however the most powerful irrational argument that has historically been used to deny rights to lesbians and gay men lie in their "supposed powers to corrupt, in both the physical and ideological senses" (Rich, 1981). These fears are based on the connections that have been made between homosexuality and bestiality, paedophilia and deviancy (Woods and Harbeck, 1992).

The myths of paedophilia, recruitment, and deviancy are frequently expressed by the media as part of an "informed debate" and little is done to promote an objective and less emotive discussion based on accurate, well researched and documented information. One only needs to examine the debate generated over the attempts at Hutt Valley High School in Lower Hutt to establish a gay and lesbian teacher support group to understand the dilemmas faced by lesbian and gay educators 
in their schools. The editor of the Dominion suggested that "Schools are no place for Role Models" (Dominion, 1993). Lesbian and gay teachers were accused of promoting the "legitimacy of their lifestyle" through establishing "a presence within the school" (Marshall, 1993. See note at end). In an Evening Post editorial it was claimed that as "heterosexual teachers do not proselytise in schools for their sexual orientation, there is no earthly reason why homosexual teachers should" (Evening Post 1993). The media in this instance were more concerned with the effects of the debate on one school rather than on the issues in general.

These claims fail to recognise that there is no need for heterosexual teachers to "proselytise" for their sexual orientation as heterosexuality has been established as the norm and any variation from this is assumed to be a "pathological affliction" (Kitzinger, 1987). The implications are that gay and lesbian teachers are a danger to youth and that any recognition or affirmation of their "lifestyle" would be damaging and corrupting to those they are in "loco parentis" of. This conservative view reinforces for the general public the view of gay men as "predatory paedophiliacs" who prey on young children and unduly influence their sexual development (Squirrell, 1989).

These experiences provide a very strong message for lesbian and gay educators: that it is dangerous and professionally suicidal to "come out" in their workplace as it will automatically render them at odds with their role of being in "loco parentis". Lesbian and gay educators are then often rendered powerless to assume a positive identity within their workplace and find it necessary to hide their sexuality and incur the consequences of doing so. The consequences: isolation, guilt, inadequacy, fear of discovery, and feelings of marginalisation, all contribute to lesbian and gay educators' feelings of stress in the workplace. It is these consequences that are constantly outlined and recurring in the literature to be discussed within this review.

\section{The Research}

The literature that has been written in the 1980s has concentrated on outlining the issues confronting lesbians and gay males within the education arena with their main agenda being to break the silence that surrounds the issue. Throughout the literature there are common themes constantly recurring which need to be discussed and analysed within this review: invisibility, isolation, and homophobia. Each of these has a significant impact on the lives of gay and lesbian educators.
The literature that concerns gay male educators falls into four main categories. These include research that combines the experiences of both lesbian and gay educators, papers that investigate the implications of challenging fundamentally heterosexist and homophobic education institutions, reflections on the research process by lesbian and gay researchers and literature on how to make schools safe for lesbian and gay students and educators.

The large majority of this literature is from overseas. In Aotearoa the quantity of published and widely available material remains small. There has been a development of resources to aid in the education process in the fight against AIDS which includes material on sexual orientation (NZ Family Planning, 1992; NZ AIDS Foundation, 1991). What is significant is the almost total lack of research and writing that specifically reflects the experiences of lesbian and gay educators and students in education. To date there has been one unpublished study completed in Aotearoa which concerns itself with the experiences of lesbian students and teachers (Stapp, 1991). However, as the experiences examined within this thesis were those of lesbian teachers and were a subsidiary to the main body of the research which concerned lesbian students, it will not be discussed in this review. In addition to this there is one unpublished study completed in Christchurch by Kathleen Quinlivan (1993) which examines the identity management of four lesbian teachers. There is no material currently available in Aotearoa that deals exclusively with issues concerning gay male experience of secondary schools.

\section{General Writing on the Subject of Homophobia and Heterosexism in} Schools

This section of the literature focuses largely on the wider issues of equity facing lesbian and gay educators and students. Grayson (1991) an American, focuses her discussion on providing a rationale for the consideration of homosexuality as an emerging equity issue citing Lorde "that if we truly intend to eliminate oppression, heterosexism and homophobia must be addressed" (p.132). Grayson offers possible solutions to the dilemmas facing schools in resolving these issues. These will be dealt with in more detail later in the review.

Andrews (1990) writing in Britain, and Chamberlain (1985) writing in the United States, both examine the complexities of designing and implementing policies aimed at challenging and confronting heterosexism in schools. Both authors suggest that this is the problem that should concern all teachers and administrators, not just those who are gay or lesbian. Chamberlain goes further to suggest that rather than 
perceiving lesbian and gay people as the problem, it would be more helpful to examine the natural bias toward heterosexuality in schools and how this effectively prevents lesbian and gay educators and students from adopting positive feelings about their sexuality.

Rofes, a gay activist and writer in the United States explored issues surrounding the failure of schools to meet the needs of lesbian and gay youth. He suggests that their needs have not been taken on board because "their voices have been silenced and because adults have not effectively taken up their cause" (Rofes, 1989:444). He goes on to make recommendations based on the experiences of Harvey Milk School in New York and Project 10 in Los Angeles, that would support the development of proactive policy to protect and provide for gay and lesbian youth and educators.

Watney (1991) deals with the effects of government legislation in the form of Section 28 of the Local Government Amendment Act (1988) on Lesbian and Gay Educators in Britain. The Act states that a local authority shall not (a) intentionally promote homosexuality or publish material with the intention of promoting homosexuality; (b) promote the teaching in any maintained school of the acceptability of homosexuality as a pretended family relationship (Harris, 1990:5-6). Watney suggests that the law itself challenges gay and lesbian teachers' very existence within schools and requires them to hide their sexuality carefully as not to do so can be seen as "promoting homosexuality" and therefore providing grounds for dismissal.

Section 28 was passed in Britain in 1988 in response to the increasing demands being placed on schools by lesbian and gay groups to provide inclusive curricula to meet the needs of lesbian and gay youth. It is possible that in Aotearoa the legislation that has recently been passed in the form of the Human Rights legislation is at risk from a similar backlash unless education processes that began with the Homosexual Law Reform in 1986 are continued and schools encouraged to adopt positive, gay and lesbian inclusive pedagogy and curriculum. At present there are no guidelines available to schools to empower them to implement such policies and practices. Until these are provided the development of safe schools will remain ad hoc and vulnerable to right wing and media backlash.

The author of this article completed the only known writing in Aotearoa examining gay and lesbian concerns as an equity issue (Town, 1993). The paper suggests that the Ministry of Education and Teacher Unions have a responsibility to ensure that schools are free of prejudice and harassment for lesbian and gay educators and youth. In providing for this, consultation with gay and lesbian education groups such as Gays and Lesbians Everywhere in Education (GLEE) as to what should be included in anti-homophobia policies would be necessary. The paper emphasises the need for a set of national guidelines to schools to ensure that their curriculum and practices are brought into line with the Human Rights Legislation (1994). This paper, however, remains unpublished.

The articles mentioned deal with the issues confronting lesbian and gay educators very generally. However they are useful because many of the same forces, heterosexism and homophobia, that operate to prevent gay and lesbian youth from coming out in schools, are similar to those which prevent lesbian and gay educators from being open about their sexuality.

In his study "Educators, Homosexuality, and Homosexual Students: Are Personal Feelings Related to Professional Beliefs" (1992a), James Sears touches on issues confronting both lesbian and gay educators and students. The study situated in South Carolina in the United States is based on interviews with students and survey data collected from school counsellors and teachers. Sears found that eight out of ten prospective teachers surveyed, harboured negative feelings toward lesbians and gay men. One third of those surveyed fell into a high grade category of homophobia. He found in surveying school guidance counsellors that there were many similarities between their perceptions and those of the preservice teachers. Although not dealing directly with the issue of lesbian and gay educators, Sears' research provides substantive reasons as to why gay and lesbian educators find it difficult to disclose their sexual orientation in their workplace. It is also significant in that it places the responsibility for dealing with homophobia and heterosexism firmly at the feet of the heterosexual world.

\section{Combined Research on Lesbian and Gay Educators}

Harbeck (1992), using modern computer retrieval techniques investigated the relationship between lesbian and gay teachers in the United States, and dismissal. Then taking an historical approach, Harbeck made comparisons between the current trends in employment rights of lesbian and gay educators and those they have had in the past. Her findings suggest that lesbian and gay educators experience considerably more personal freedom and rights within their workplaces than they have had in the past.

Through a process of collective reflection and action research methods, a study carried out by Pat Griffen (1992) in the United States 
empowered lesbian and gay teachers to begin a process of coming out in their workplace. Griffen interviewed thirteen teachers, six men and seven women individually and then as a group over several months. As the process developed the participants found it possible to be more open about their sexuality, felt less isolated and less afraid of being identified as lesbian or gay in their workplaces.

Griffen, through discussions with her research participants provides a model as a starting point for discussing the experiences of gay and lesbian teachers and the effects that their sexuality has on their daily lives. She suggests a continuum of identity management beginning at one end with "passing" (the attempt to lead colleagues and students to believe they are heterosexual) through to being publicly out (which is seen as a high risk strategy). Griffen's work is useful in that she provides a developmental model with which to examine the management strategies of lesbian and gay educators.

Finally, Squirrell in her British study "In Passing... Teachers and Sexual Orientation" (1989) interviewed twenty five gay and lesbian educators from a variety of backgrounds and ages. She focused her research on how lesbian and gay teachers managed their working lives, teacher-pupil interaction and the differences between the experiences of lesbian and gay educators. Squirrell found that her participants felt that knowledge of their gay or lesbian identity would discredit them professionally both inside the classroom with students and in their careers as teachers with colleagues. The greatest fear held by the participants in this study was that they would lose their jobs and promotional prospects. Squirrell focused a large part of her research on the differences between lesbian educators and gay educators. Lesbian educators felt more vulnerable in their schools and were less likely to be promoted than gay men. Squirrell identified one of the reasons for this as being that gay men frequently used female colleagues as "cover" to help them "pass" as heterosexual, therefore having access to all the privileges a heterosexual male had within the school system in terms of credibility and promotion. This was not seen as an option by the lesbian educators in Squirrell's study These findings are also supported by the findings of Quinlivan in her work in Aotearoa and Griffen in the United States.

\section{Creating Safe Schools}

There is now a variety of published programmes which provide valuable information and guidelines for creating safe schools for lesbian and gay youth: The Harvey Milk School New York, Project 10 attached to Fairfax
High School, Los Angeles and the Massachusetts Safe Schools Programmes.

These programmes approach the problem of providing a safe and inclusive learning environment for lesbian and gay youth from a variety of perspectives. The Harvey Milk School arose out of a response to local need. The school was originally established as a "drop in" support centre for gay and lesbian youth opening after school hours to cater for lesbian and gay youth who needed a safe place to go to. The volunteers running the centre found that many of the youths who were frequenting the centre were arriving and waiting on the doorstep first thing in the morning as they were truanting from their high schools. The lesbian and gay youth who were truanting had been victims of verbal and physical abuse in their schools and homes and had fallen into a pattern of truancy as a result. In response to this the administrators applied to the state government for funding as a school to allow the youth to continue with their studies in a safe environment. The application was successful. In 1991 it had a roll of approximately 25.

The issue that is significant in this process is one of segregated or separate schooling for lesbian and gay youth by lesbian and gay teachers. Critics of the school claim that it does not force mainstream schools to address the issues of homophobia and heterosexism and effectively removes the "problem" elsewhere. However, the history of the establishment of the school needs to be examined in terms of the rationale for its establishment. It was meeting an immediate need that was not being catered for in the mainstream. The school has also attracted "second chance" adult students who left school early as a result of their feelings of isolation and harassment in the mainstream.

Project 10 established at Fairfax High School in California approaches the issue from within the mainstream. It is a school-wide project, established once again in response to an identified need. Young lesbian and gay students within the school had been victims of homophobic attacks and teachers and counsellors had been unable to address their needs. Project 10 is an education programme that focuses on providing a safe learning environment for lesbian and gay youth through running anti-homophobia workshops with staff and students, creating lesbian and gay-only space within the school and disciplining students who exhibit homophobic behaviours. In response to this programme Fairfax has attracted lesbian and gay students from other schools.

The Massachusetts Safe Schools Programme similarly seeks to address the needs of lesbian and gay youth within the mainstream. It is 
significant for its state wide approach. The underlying ethos of the programme is one of addressing and changing negative behaviour. Students who exhibit homophobic attitudes and behaviour are removed from the school and suspended. The students who continue with this homophobic behaviour are suspended indefinitely. As well as this the programme contains workshops for teachers and students that address the needs of lesbian and gay youth and seek to educate the community in the damaging results of homophobic behaviours and heterosexist bias.

Although these reports focus on strategies for change that would enable schools to create safe learning environments for lesbian and gay youth it is important to discuss this literature in terms of what it can achieve for gay and lesbian educators. In Aotearoa there have been similar attempts to provide schools with resources to enable homophobia to be addressed within the curriculum. Publications such as Affirming Diversity and Straight Talking were produced by the Family Planning Association and the New Zealand AIDS Foundation respectively and distributed to schools. The resources contain workshops on how to counter homophobia and were intended for use within the Health syllabus.

However without a mandate from central government, and a climate in which the issues can be openly discussed these resources are underused as schools are unable to grapple with negative reactions from the parent community. This reinforces the need for the state-wide approach that has been adopted in Massachusetts. Without this approach many schools prefer to bury their heads in the sand and deny the existence of the issues. This was clearly demonstrated by the actions of the principal of Hutt Valley High School in not allowing the establishment of a gay and lesbian support group within his school.

One of the issues that needs to be made more explicit in the literature is to bring the world of the gay or lesbian teacher and the world of the gay or lesbian student together. The enforced separation of these groups within the education institution maintained through the myths of recruitment, paedophilia and deviancy perpetuates the feelings of isolation and invisibility felt by both groups. The programmes outlined above provide valuable strategies that can be employed to reduce this gap and recognise the contribution that lesbian and gay teachers can make to the lives of lesbian and gay students.

\section{The Research Process}

Sears (1992b) explores the use of qualitative research methods in examining homosexuality in education. He bases his discussion on research he carried out involving interviews with thirteen young gay and lesbian men and women. He describes the interviews as a "cacophony of voices" that explore the conflicts between public and private worlds in the south of the United States.

Sears explains that the power of qualitative data lies in the ability of the researcher "to know well a few people in their cultural contexts". He stresses the importance of seeing the participants in the context of their whole lives and the roles that gender, class, race and sexuality play within that context in contributing to their whole identity. He goes on to suggest that the use of critical theory, unlike quantitative methods of research, is significant in being able to describe and account for the contradictions, contestation and resistance that is found in the everyday lives of teachers, students and parents.

Sears goes on to discuss the dilemmas of political correctness within research, suggesting that qualitative work is often criticised for the political correctness of its messages rather than attracting comment based on its findings. He points out that the interests of qualitative research are possibly at odds with the communities being researched. In the instance of lesbian and gay issues qualitative research requires the researcher to deconstruct the politics of sexual identity and in so doing deconstruct "the very communities that have given gay men and lesbians their collective identities" (ibid:154).

He ends however, by suggesting four areas on which future research could be focused: the influence of childhood events on the present identities of homosexual adults, how the construction of sexual identity varies between people, how race and gender contribute to the development of a gay or lesbian identity and finally the degree to which activists apply structural analyses in their everyday political struggles.

Griffen (1992) focused her research on the process of empowerment in selecting participants who were not "out" in their school, and providing a forum in which the participants were able to explore the reasons why and the effect that this was having on their lives. The result of this was that all of the participants moved from the "concealment" of their sexual orientation to a point of "disclosure" in their workplace. The study took one year to complete. The smaller scale of my research project does not allow for this complete process to occur. The choice to focus on coping strategies used by already "out" gay teachers does allow for an examination of positive rather than "negative" behaviours, and it allows the participants to concentrate on identifying and clarifying the contradictions inherent in their professional lives. 
Quinlivan (1993), conducted two open-ended, individualinterviews with four lesbian teachers in Christchurch. She incorporated within her research design participatory research and feminist research methods. Quinlivan's interviews were with teachers who felt they were able to talk openly about their experiences and therefore her data does not reflect the perspective of closeted lesbians. This has influenced the design of my own project. Recognising the difficulties inherent in trying to establish a discourse with closeted teachers I have chosen to focus my research on teachers who are "out" in both their personal and working lives.

\section{Research Findings}

The findings of the research can be examined by exploring a number of common themes found in the literature: the invisibility of gay male educators, a description of the experiences of gay male educators, the strategies that gay male educators adopt to cope in both their personal and working lives, the effects that these coping strategies have on their lives, differences between the experiences of gay male and lesbian teachers and finally, the strategies that the researchers suggest would bring about change.

The invisibility of lesbian and gay issues in all spheres and at all levels of the education process is identified as one of the major concerns. Watney (1991:388) reports that education systems manifestly fail to acknowledge the actual diversity of human sexuality either within the curriculum or outside it. In effect children are taught that homosexuality is beyond consideration. This is significant for gay teachers as having experienced the education system themselves, they internalise this homophobia and carry it into their classrooms. This is particularly significant in the context of Watney's work. He also examines the impact of local council legislation, which prevents the "promotion of homosexual lifestyles" in schools. This further alienates and contributes to the invisibility of the gay educator and the gay student by preventing the provision of an environment where issues concerning sexuality can be openly and positively explored. The legislation also contributes to reinforcing gay educators' fears about job security and career prospects.

This invisibility is often perceived as an absolute requirement by gay male teachers if they expect to continue in their chosen profession. Those "most likely to suffer dismissal from work are gay men who are employed in working with children" (Daly, cited in Squirrell, 1989:8). They are likely to suffer dismissal from their positions because of the homophobia that pervades school communities and the physical and ideological corruption that gay men are accused of.
Another factor that contributes to the need for gay male teachers to hide their sexuality in their workplace is the harassment that occurs when their sexuality is public knowledge. Grayson (1991) found that many of her respondents shared stories of "repeated incidents" pertaining to "vicious rumours", threats, anonymous phone calls, defacement of personal and professional property, verbal and physical abuse, and other forms of physical, emotional and mental abuse. These findings were supported in the research of Squirrell (1989) and Griffen (1992).

Chamberlain (1985:303) points out that the issue remains invisible and that professionals are hesitant to raise it because they are "running scared, nervous about parents' reactions, worried about losing their jobs and guarded about issues discussion of which might expose their private lives". This accounts to some degree for the invisibility of gay and lesbian role models in schools.

Closely related to the issue of invisibility is the isolation that is felt by gay male educators in their work environment. The need to conceal their true identities affects the relationships gay male teachers have with both their colleagues and their students. Squirrell (1989) found that gay male educators lead secretive lives in their workplaces out of the fear that to be honest about their sexuality would affect their job security, their prospects for promotion and their credibility. Griffen (1992) found that her research participants "believed universally that to be 'out' in school would cost them their jobs".

In protecting these beliefs gay male teachers find it necessary to separate strictly their personal and professional lives. Grayson (1991) identifies this as gay teachers having to maintain a "dual identity". To manage this effectively there are a number of identifiable personal costs. They have to live with the daily fear of being discovered, isolate themselves from students and other teachers to avoid detection, and hope that by being excellent and conscientious teachers their jobs will be protected even if their sexuality becomes common knowledge.

When put alongside the findings of Sears (1992a) who found that one third of prospective teachers in South Carolina in the United States held high homophobic beliefs, together with his findings of harassment and lack of support from colleagues and administration, it is hardly surprising therefore that gay male teachers sense that it is not in their best interests to acknowledge their sexuality in the workplace.

Compounding these feelings of isolation is the guilt associated with dishonesty about their personal lives (Squirrell, 1989; Quinlivan, 1993). Many gay male teachers feel frustration and anger at having to lead a 
double life, which in turn places strains on personal relationships. Many feel it difficult to establish and maintain relationships, throwing themselves completely into their work and using public sex venues to satisfy their need for gay contact. In this respect many find it difficult to pursue emotionally satisfying relationships out of fear that their sexuality will be discovered. The effect of this internalised homophobia is traumatic for gay male teachers and often contributes to a pervasive feeling of self hatred.

A recent manifestation of homophobia is to be found within the effects of the AIDS crisis. One gay male teacher found that after a prolonged absence his ability to continue in his position was rendered impossible because people perceived him as a victim of the disease. This was not so (Squirrell, 1989).

Squirrell (1989), Sears (1991), Griffen (1992) and Quinlivan (1993) suggest that there are differences between lesbian and gay teachers' experiences within schools. However, a significant amount of the literature combines the experiences of both groups and assumes that there is a homogeneity to their experience. It appears that gay males experience a different yet complementary set of pressures to that of their lesbian counterparts, largely due, it seems, to the way in which gender roles are defined, and the expectations that this places on behaviour. This is an area of research that needs to be investigated further.

\section{Suggestions for Change}

The strategies for change suggested by the literature occur at a number of levels and can be placed on a continuum moving from the individual through the community to government level. The changes that need to occur involve national and state policy, individual schools policy, curriculum and assessment, teacher development and personnel training, counselling and support and more research and information.

Many of the authors express frustration at the slow pace of change and the increased difficulties arising from the lack of supportive government legislation. Squirrell (1989), Watney (1991), Griffen (1992) all examine the negative impact of homophobic national and state wide legislation that provides no legal support for lesbian and gay educators in their work places in the United States and Britain. 1994 saw the implementation of legislation to protect lesbians and gays in Aotearoa. Town (1993) points out that the legislation although significant, needs to be reinforced through a process of community education if it is to have any effect on reducing prejudice and homophobic behaviour.
Within the wider context of legislative change it was seen that schools and communities need to develop localised policies of support for lesbian and gay students and teachers (Squirrell, 1989; Grayson, 1991; Town, 1993; Hebert, 1993). Grayson suggests a four step approach: programmes aimed at increasing awareness, examining attitudes, a focus on alternatives and supportive action.

Squirrell (1989), Grayson (1992), Chamberlain (1985) and Andrews (1990) examine the dangers of identifying the problem as a gay or lesbian one to be solved through individual counselling. They suggest that an exploration of the ways in which prejudice manifests itself in society and how it is perpetuated throughout the education process is necessary to enable parallels between homophobia and other types of prejudice to be seen and understood. In this respect homophobia is as much, if not more so, a heterosexual problem as a gay or lesbian one. Therefore as Sears (1992) suggests heterosexual teachers and counsellors need to address their own fears and prejudices regarding homosexuality.

Closely related to this idea is the need outlined in the literature for teacher development and personnel training. Grayson (1991), Andrews (1990) and Sears (1992) indicate that teachers and those involved in confronting their own heterosexism and homophobia, need to examine not only their personal attitudes and beliefs but also their teaching practices and content. Squirrell (1989), Woods and Harbeck (1992) stress how important raising teacher awareness is in affecting change. Staff need to be equipped to deal with instances of verbal abuse and harassment between students, between students and staff and between colleagues. Woods and Harbeck (1992) go on to emphasise the significance of supportive administrative structures in dealing with overt homophobic behaviours.

Quinlivan (1993) recommends the development of policies within school charters to protect lesbian and gay students and teachers from discrimination, professional development for teachers about homophobia and how to challenge it in their classrooms, training for counsellors as to the needs of lesbian and gay students and teachers, curriculum development and the sponsorship of research. These recommendations are significant in that they provide a comprehensive overview of what areas within schools need to be changed if an environment inclusive of lesbian and gay needs is to be provided. They have also been developed in Aotearoa in response to research undertaken here. However, until material such as Quinlivan's is published and further research undertaken the recommendations arising from such work will continue to go largely unnoticed. 
As Quinlivan (1993) suggests the curriculum is perceived as a significant area in need of change. Andrews (1990) and Chamberlain (1985) suggest that the ways in which heterosexism manifests itself in the curriculum is an area that needs to be examined. They argue that the way in which few alternatives to the heterosexual family structure are given needs to be reassessed along with the way in which gender and sexual stereotyping is perpetuated within subject areas. In this regard schools need to make sure that texts and teaching materials do not present negative images of lesbians and gay men and lifestyles and to look at ways an across-the-curriculum approach can be implemented. As well as this, libraries need to be culled of all obsolete and negative information and restocked with positive and accurate novels, articles and non-fiction.

Finally the literature recognises the degree to which lesbian and gay teachers are isolated within their schools. Harbeck (1992) suggests that an effective strategy to deal with this is for support groups to become established. These groups could operate on a number of levels. They would enable gay and lesbian teachers to establish support for themselves, examine the issues confronting them in their daily lives and provide a forum to discuss which ways change can be effected. Griffen (1992) and Chamberlain (1985) suggest that gay and lesbian teachers need to forge stronger links with other groups and with supportive heterosexual colleagues to ensure that teachers, students and administrators are fully informed and supportive of gay and lesbian issues. This is particularly important in light of the changes to the Human Rights Legislation in Aotearoa.

\section{How Valuable is this Literature?}

Research into lesbian and gay issues in education is a relatively new phenomenon. Each of the articles cited is significant in terms of the contribution it makes to reducing the silence and breaking down the myths that surround the subject. It is important to note that at the time of writing this review there appears to be little research available that focuses exclusively on the experiences of gay male teachers in Aotearoa and there is no published research that explores the experiences of gay male or lesbian teachers in the context of Aotearoa.

It has been argued that the combined research that does exist elsewhere (Squirrell, 1989; Griffen, 1991) favours the experience of gay males over their lesbian counterparts. However, this is difficult to establish, as the focus of the research tends to be on the common experiences the two groups share rather than on the differences. Both
Squirrell and Griffen suggest that research that examines the experiences of gay males independently of lesbians is necessary to understand more fully the complexities surrounding lesbian and gay issues in education. This view is also supported by Sears (1991) who recognises the role that gender plays in determining experience. The result of focusing on combined and shared experiences between lesbians and gay males has led to many of the issues being dealt with superficially.

The general writing on homophobia and heterosexism is significant in that it provides a political framework for discussion and takes the issue away from the personal. Thus the role of government, in providing legislation that protects lesbian and gay teachers, is seen as being as significant as local school policies in effecting change. (Grayson, 1991; Rofes, 1989). However, the literature relies on a description of discriminatory legislation and homophobic behaviours rather than providing research that provides the perspective of gay male teachers. In this respect it is necessary to move beyond simply suggesting strategies for change without examining and exploring the way in which gay male teachers perceive their positions within education institutions.

There is a need to place the personal experience of gay male teachers within these political frameworks and to examine the resistances that they have developed in working within primarily heterosexist institutions. Providing a forum in which the experiences of gay male teachers can be explored is an important step in gaining any form of political and attitudinal change. I intend to explore this issue in my further research and focus on the successful and positive, rather than the negative survival strategies that the participants have used to overcome these homophobic and heterosexist environments. This will provide useful strategies for change.

The teachers involved in Griffen's study (1992) found the process personally and professionally empowering. Their stories gained significance when placed within the institutional framework from which they originated. This is important as it allowed their stories to be seen within a political framework emphasising that the responsibility for change lies not only with gay and lesbian teachers but also with the institutions and policy makers themselves. This is supported in Sears' (1991) work when he examines the homophobic attitudes of teachers, suggesting that these attitudes must be addressed if change is to occur. Both he and Squirrell (1989) point out the important role that heterosexual teachers have to play in overcoming the barriers facing gay and lesbian students and teachers in their workplace. 
When combined with the action plans suggested in the documents, the different levels at which change needs to occur and at which education needs to be directed, are clearly outlined. Town (1993), Andrews (1990), Chamberlain (1985) and Quinlivan (1993) suggest that change needs to occur simultaneously at a number of levels. The writing of these articles is a beginning. Sears (1992a), Squirrell (1989) and Woods and Harbeck (1991) recognise the need to move beyond description to proposing strategies for change. Many of the recommendations found within these documents are useful in designing policy and practice to protect lesbian and gay students and teachers in Aotearoa.

\section{Conclusion}

The literature that is available has been imported through overseas interloan services offered by Victoria University library. The fact that it is not readily available in Aotearoa reflects the degree of silence and invisibility that surrounds issues of sexuality within the education arena. The work that is available is largely exploratory of the issues and concerns of lesbian and gay educators and researchers. The literature offers a variety of perspectives and strategies for change. However, there continues to be a need for research and analysis in greater depth, the greatest need being for research to be carried out in the context of Aotearoa. With the passing of the Human Rights Amendment Act 1993, there is a clear need to discover how the forces of homophobia and heterosexism operate within school communities if discrimination against lesbians and gay men is to come to an end. This provides a clear rationale for further research into the status and experiences of gay teachers and students, to enable the issues of concern to them to be framed within the political and institutional spheres in which they conduct their personal and professional lives.

\section{Note}

Graeme Marshall is the principal of Hutt Valley High School. One of his responses to the establishment of a lesbian and gay teacher support group at his school was to write a letter to staff and the community accusing Gays and Lesbians Everywhere in Education (GLEE) of trying to establish a presence in his school.

\section{References}

Andrews, J. “Don't Pass Us By: Keeping Lesbian and Gay Issues on the Agenda" in Gender and Education, 2:3, 1990.
Chamberlain, P. "Homophobia in Schools, Or What We Don't Know won't hurt us", In S. Cushee O'Malley, R. Rosen and L. Vogt (eds), Politics of Education: Essays from Radical Teacher, Albany: State University of New York Press, 1985.

Department of Education. Charter Development and Equity, Implementation Unit, Wellington: Government Print, 1988.

Dominion. Editorial "Schools are no Place for Role Models", 26 October, 1993.

Evening Post. Editorial "Diminishing Logic", 3 November, 1993.

Goggin, M. "Gay and Lesbian Adolescence" in S. Moore and D. Rosenthal (ed), Sexuality and Adolescence, London: Routledge, 1993.

Governor's Commission on Gay and Lesbian Youth. Making Schools Safe for Gay and Lesbian Youth: Breaking the Silence in Schools and in Families, Boston: Department of Education, 1993.

Grayson, D. "Emerging Equity Issues Related to Homosexuality in Education" in Peabody Journal of Education, 1991.

Griffen, P. "Lesbian and Gay Educators: Opening the Classroom Closet" in K. Harbeck (ed), Coming Out of the Classroom Closet, New York: Harrington Press, 1992.

Harbeck, K. "Gay and Lesbian Educator Past History/Future Prospects", in K. Harbeck (ed), Coming Out of the Classroom Closet, New York: Harrington Press, 1992.

Harris, S. Lesbian and Gay Issues in the English Classroom, Buckingham: Open University Press, 1990.

Hebert, G., (ed). Massachusetts Safe Schools Program for Gay and Lesbian Students Books 1 \& 2, Learning Support Services, Boston: Dept of Education, 1993.

Hetrick, E and Martin, A. The Stigmatization of the Gay and Lesbian Adolescent, New York: Haworth Press, 1988.

Kitzinger, C. The Social Construction of Lesbian Identity, London: Sage Publications, 1987.

Lather, P. Getting Smart: Feminist Research and Pedagogy with/in the Postmodern, New York and London: Routledge, 1991.

Lorde, A. There is No Hierachy of Opression, publisher unknown, 1983.

Mac An Ghalil, M. "Schooling, Sexuality and Male Power: Towards an Emancipatory Curriculum" in Gender and Education, 3:3, 1991.

Marshall, G. Newsletter to Parents of Hutt Valley High School, 1 November, 1993. 
Moore, S. and Rosenthal, D. "Sexuality and Adolescent Development: Theoretical Perspectives" in Sexuality and Adolescence, London: Routledge, 1993.

Moore, S. and Rosenthal, D. "Gendered Constructions of Sexuality" in Sexuality and Adolescence, London: Routledge, 1993.

New Zealand AIDS Foundation. Straight Talking, Auckland: New Zealand AIDS Foundation, 1991.

New Zealand Family Planning. Affirming Diversity, Auckland: A Resource for Schools, 1992

Quinlivan, K. "Voices from the Margins: The Identity Management of Lesbian Secondary School Educators", unpublished Research Paper, University of Canterbury, 1993.

Rich, A. "Compulsory Heterosexuality and Lesbian Existence" in The Lesbian and Gay Studies Reader, H. Abelove, M. Barale, D. Halperin (eds), New York: Routledge, 1993.

Rofes, E. "Opening Up the Classroom Closet: Responding to the Educational Needs of Gay and Lesbian Youth" in Harvard Educational Review, 59:4, President and Fellows of Harvard College, November 1989.

Rose, R. "Gay and Dead" in The Listener, May 8, 1993.

Schneider, S. "Suicidal Behaviour in Adolescent and Young Gay Men in Suicide" in Life Threatening Behaviour, 19:4, Los Angeles: The American Association of Suicidology, 1989.

Scott, P. "Challenging Heterosexism in the Curriculum: Roles for Teachers, Governers and Parents" in C. Jones and P. Mahoney (eds), Learning our Line Sexuality and Social Control in Education, London: The Women's Press, 1989.

Sears, J. Growing up Gay in the South, New York: Haworth Press, 1991.

Sears, J. "Educators, Homosexuality and Homosexual Students: Are Personal Feelings Related to Professional Beliefs?" in K. Harbeck (ed), Coming Out of the Classroom Closet, New York: Harrington Park Press, 1992a.

Sears, J. “Researching the Other/Searching for Self: Qualitative Research on (Homo) Sexuality in Education" in Theory into Practice, (Special Issue: Qualitative Issues in Educational Research), 31:2, 1992b:147156.

Squirrell, G. "In Passing... Teachers and Sexual Orientation" in S. Acker (ed), Teachers, Genders and Careers, London: Falmer Press, 1989.
Stapp, A-M. “Coming Out as a Young Lesbian: The Effects of Secondary School Environment on Young Women Being Able to Identify as Lesbian". Unpublished Thesis, Victoria University, 1991.

Stewart, T. Invisible Families, Dunedin: New Women's Press, 1993.

Taylor, B. "Gay and Lesbian Youth Services in New Zealand" - a Discussion Paper, Youth Mental Health Project, Wellington, 1991.

Town, S. "Fairytales can Come True: Equity Issues and Policy Development concerning Inclusion of Gay and Lesbian Members of Education Institutions in Aotearoa", unpublished M.Ed paper, Victoria University of Wellington, 1993.

Trentchard, L. and Warren, H. Something to Tell You, London: London Gay Teenage Group, 1984.

Warren, H. Talking About School, London: London Gay Teenage Group, 1984.

Watney, S., (ed). "School's Out in Fuss", in Inside Out: Lesbian Theories, Gay Theories, New York: Routledge, 1991.

Weeks, J. "Questions of Identity" in Against Nature: Essays on History", Sexuality and Identity, London: Rivers Oram Press, 1991.

Weeks, J. "The Value of Difference" in Against Nature: Essays on History, Sexuality and Identity, London: Rivers Oram Press, 1991.

Woods S. and Harbeck K. "Living in Two Worlds: The Identity Management Strategies Used by Lesbian Physical Educators" in K. Harbeck (ed), Coming Out of the Classroom Closet, New York: Harrington Park Press, 1992.

\section{The author}

Shane Town has been an English teacher at Heretaunga College for the last ten years. In 1994 he took leave from teaching to complete his Master of Education degree. He has been awarded a post graduate scholarship for PhD study at Victoria University for 1995-1996. He is currently researching the experiences of gay male youth and teachers in secondary schools in Aotearoa. 